Vol. 24, No. 2, April 2021, hlm. 319-330

p-ISSN: 1410-9344; e-ISSN: 2549-5631

WARTA LPM

homepage: http://journals.ums.ac.id/index.php/warta

\title{
Perencanaan Keuangan dan Sumber Daya Manusia sebagai Upaya Perbaikan Tata Kelola Bisnis dalam Menghadapi Masa Krisis Akibat Covid-19
}

\author{
${ }^{1}$ Dito Rinaldo, ${ }^{2}$ Puteri Andika Sari, dan ${ }^{3}$ Wiendy Puspita Sari \\ Sekolah Tinggi Ilmu Ekonomi Ekuitas \\ Email: ${ }^{1}$ rinaldo.dito09@gmail.com, ${ }^{2}$ puteri.andika31@gmail.com, ${ }^{3}$ wiendy.ps@gmail.com
}

\section{Article Info}

Submitted: 29 September 2020

Revised: 9 November 2020

Accepted: 9 December 2020

Published: 21 April 2021

Keywords: Business

Governance, Financial Planning,

HR Planning and Covid-19
Kata kunci: Tata kelola

Bisnis, Perencanaan Keuangan, Perencanaan SDM dan Covid-19

\section{Abstract}

As we all know, what is an obstacle in business development is the governance of internal resources. This is also faced by start-up entrepreneurs, for example students who are entrepreneurs. This community service program aims to strengthen the business governance of STIE EKUITAS entrepreneurial students ("studepreneurs") through financial planning and human resource management (HR). The program is implemented in the period January - April 2020. The service method used is mentoring and training by adopting Ken Watanabe's concept of problem solving 101. The results of the service program show that there is an increased understanding of how to prepare financial and human resource planning. Participants are able to allocate their income into emergency fund posts, investments, installments and necessities with the concept of $10+20+30+40$ effectively. In the field of human resources, participants are able to perform job analysis, compile job descriptions, job specifications and calculate the number of employee needs using the Workload Analysis theory. It is hoped that through this program members of the study program will be ready to face any situation, including the possibility of a crisis caused by the Covid-19 pandemic.

Abstrak
Sebagaimana kita ketahui bahwa yang menjadi kendala dalam
pengembangan bisnis adalah tata kelola sumber daya internal. Hal
ini pun dihadapi oleh start-up entrepreneur, misalnya mahasiswa
yang berwirausaha. Program pengabdian kepada masyarakat ini
bertujuan memperkuat tata kelola bisnis mahasiswa wirausaha
STIE EKUITAS (studepreneur) melalui perencanaan keuangan serta
manajemen Sumber Daya Manusia (SDM). Program dilaksanakan
pada periode Januari-April 2020. Metode Pengabdian yang digunakan
adalah pendampingan dan pelatihan dengan mengadopsi konsep
problem solving 101 dari Ken Watanabe. Hasil program pengabdian


menunjukkan terdapat peningkatan pemahaman cara menyusun perencanaan keuangan dan SDM. Peserta mampu mengalokasikan pendapatan mereka kedalam pos dana darurat, investasi, cicilan, dan kebutuhan dengan konsep 10+20+30+40 secara efektif. Pada bidang SDM peserta mampu melakukan analisis pekerjaan, menyusun job description, job specification, dan menghitung jumlah kebutuhan pegawai dengan teori Workload Analysis. Diharapkan melalui program ini anggota studepreneur siap menghadapi situasi apapun, termasuk kemungkinan krisis yang disebabkan pandemi Covid-19.

\section{PENDAHULUAN}

Usaha Mikro Kecil Menengah (UMKM) pada umumnya memiliki tata kelola yang kurang baik, kurangnya pengetahuan dari pengelola mengenai hal ini, menjadi kendala implementasi konsep tata kelola pada UMKM, selain itu juga penerapan tata kelola yang baik membutuhkan biaya tidak sedikit, dan ini memberatkan pelaku UMKM untuk menggunakannya. Dibutuhkan pengetahuan dan kesadaran bagi para pelaku UMKM, bahwa tata kelola yang baik merupakan keharusan untuk menjadikan bisnis mereka tumbuh berkesinambungan. Prinsip dasar tata kelola yang meliputi transparansi, akuntabilitas, responsibilitas, kemandirian, dan keadilan dapat diterapkan pada UMKM di berbagai aspek yaitu aspek keuangan, operasi, sumber daya manusia, dan pemasaran.

Penerapan tata kelola menjadikan sistem pengendalian, proses operasional berjalan lebih maksimal, selain itu konflik kepentingan dan berbagai kecurangan dapat diminimalkan. Cadbury Committee, as cited in Daniri (2005) argues that GCG is a principle that can direct and control the company to achieve a balance between strength and authority of the company in giving responsibility to the shareholders in particular, and stakeholders in general. Rinaldo et al. (2018) menemukan bahwa bisnis kecil yang memiliki tata kelola lebih baik akan bertahan dan berkembang, sementara bisnis kecil dengan tata kelola yang buruk akan mengalami kebangkrutan. Selanjutnya El-Fotouh (2009) menyatakan setidaknya terdapat tiga alasan mengapa UKM perlu menerapkan prinsipprinsip Good Corporate Governance (GCG), diantaranya: (1) meningkatkan kepercayaan investor bahwa dengan penerapan GCG pada UKM akan mendorong pertumbuhan UKM, (2) meningkatkan kapabilitas pengendalian internal UKM, dan (3) meminimalkan praktik-praktik kecurangan oleh para karyawan.

Pandemi Covid-19 yang saat ini terjadi membuktikan pentingnya tata kelola yang baik, perusahaan dengan tata kelola lebih baik memiliki peluang lebih besar untuk bertahan dimasa krisis ini. Kebijkan-kebijakan pemerintah dan ketakutan masyarakat untuk beraktivitas membuat pelaku bisnis kehilangan kas yang cukup besar, tidak sedikit pelaku UMKM yang gulung tikar hanya beberapa bulan setelah Covid-19 masuk ke Indonesia, kondisi demikian juga dialami oleh anggota studepreneur STIE EKUITAS yang merupakan komunitas mahasiswa wirausaha. Seluruh anggota menyatakan mengalami kesulitan keuangan sejak diberlakukannya lockdown, dan kondisi tersebut terus berlangsung hingga saat ini, sehingga sulit menjalankan bisnis. Risiko ini sebenarnya dapat diminimalkan apabila anggota studepreneur menerapkan konsep tata kelola yang baik dalam bisnis mereka. Tim juga mengidentifikasi fenomena masalah lainnya dari beberapa angkatan studepreneur, setelah mengikuti program studepreneur ternyata hanya rata-rata $5 \%$ yang bisnisnya bisa bertahan, namun perkembangannya cenderung lambat.

Hasil survei awal juga menunjukkan bahwa anggota studepreneur tidak melakukan perencanaan keuangan dengan baik, 76\% anggota studepreneur tidak menyisihkan dana darurat, hanya $25 \%$ yang menyisihkan akan tetapi itupun tidak rutin dilakukan. Sementara itu terkait pemahaman cicilan yang diperbolehkan dalam perencanaan keuangan, $100 \%$ anggota studepreneur tidak memahami berapa persentase cicilan dari pendapatan yang diperbolehkan padahal mereka membutuhkan 
dana untuk pengembangan bisnis mereka. Sejumlah 23 dari 25 total anggota studepreneur, tidak menetapkan persentase kebutuhan dari total pendapatan, dan umumnya mereka sering menggunakan kas yang mereka peroleh untuk keperluan pribadi di luar bisnis. Selain buruknya perencanaan keuangan, ternyata perencanaan SDM juga buruk. Para anggota studepreneur tidak menghitung kebutuhan pegawai berdasarkan target pendapatan, aktivitas dan standar waktu yang dibutuhkan dalam menyelesaikan aktivitas. Mereka juga tidak membuat deskripsi pekerjaan dan spesifikasi pekerjaan, serta pekerjaan dilakukan secara serabutan.

Berdasarkan fenomena-fenomena masalah di atas, maka program pengabdian yang akan dilakukan adalah pendampingan dan pelatihan kepada anggota studepreneur dalam menyusun perencanaan keuangan dan SDM. Diharapkan melalui program ini dapat memperbaiki tata kelola bisnis mereka, sehingga para anggota studepreneur mampu mengelola bisnis dengan baik dan siap menghadapi situasi tidak terduga seperti terjadinya krisis yang diakibatkan Covid-19.

\section{METODE}

Tahapan pengabdian dilakukan oleh tim dengan mengadopsi konsep pemecahan masalah dari Ken Watanabe (2009), yaitu Problem Solving Kid. Konsep ini mengatakan, untuk menyelesaikan permasalahan dengan baik perlu melakukan beberapa tahap. Tahapannya dapat dilihat pada Gambar 1.

Berdasarkan tahapan problem solving kid tim melakukan program pengabdian, tahap pertama yang tim lakukan adalah mengenal permasalahan bisnis anggota studepreneur dengan cara analisis situasi, kemudian melakukan identifikasi akar permasalahan sesungguhnya, lalu menyusun alternatif solusi, dan pada tahap akhir menentukan solusi terbaik untuk diimplementasikan pada program pengabdian guna menyelesaikan permasalahan yang dihadapi anggota studepreneur. Berikut uraian tahapan yang akan dilakukan dalam program pengabdian.

\section{Tahap 1. Memahami Situasi}

Pada tahap ini tim berupaya mengidentifikasi: "apakah anggota studepreneur mendapatkan masalah dalam mengembangkan bisnis?", terutama pada masa pandemic Covid-19. Tim akan melakukan wawancara kepada beberapa anggota studepreneur, dengan tujuan memperoleh data kondisi existing bisnis yang dijalankan oleh anggota studepreneur, dengan demikian tim akan mampu mengenali permasalahan bisnis dengan baik.

\section{Tahap 2. Mengindentifikasi Akar Permasalahan}

Setelah tim memperoleh data mengenai kondisi existing dan memahami masalah yang dihadapi, selanjutnya tim membuat hipotesis alternatif dan rasional akar permasalahan yang mungkin menjadi penyebab utama masalah terjadi. Untuk kemudian hipotesis tersebut diujikan guna memastikan hipotesis yang dibuat oleh tim terbukti benar. Pengujian dilakukan dengan melakukan survei kepada anggota studepreneur.

\section{Tahap 3. Mengembangkan Tindakan/Solusi Efektif}

Pada tahap ini tim akan mengembangkan alternatif solusi yang efektif bagi akar permasalahan.

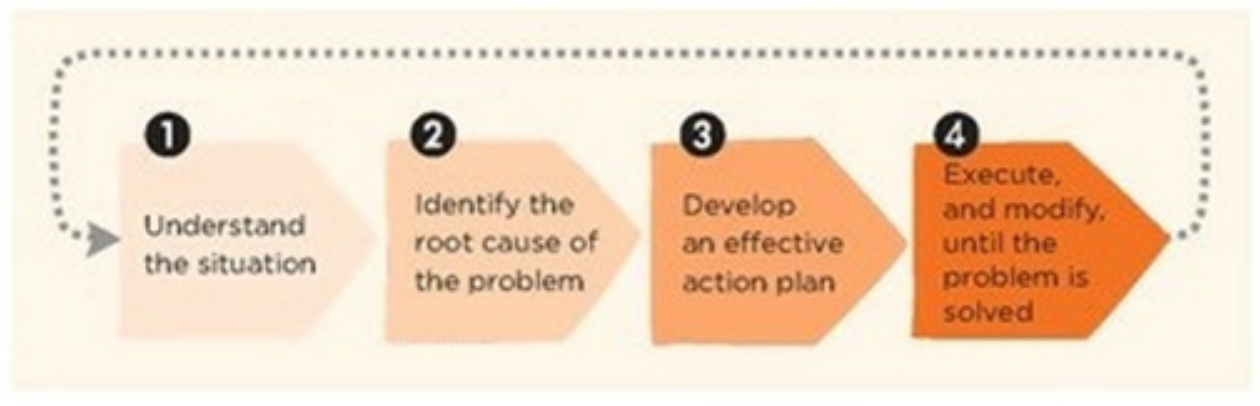

Gambar 1. Tahapan Pengabdian Menggunakan Konsep Problem Solving Kid (Ken Watanabe, 2009) 


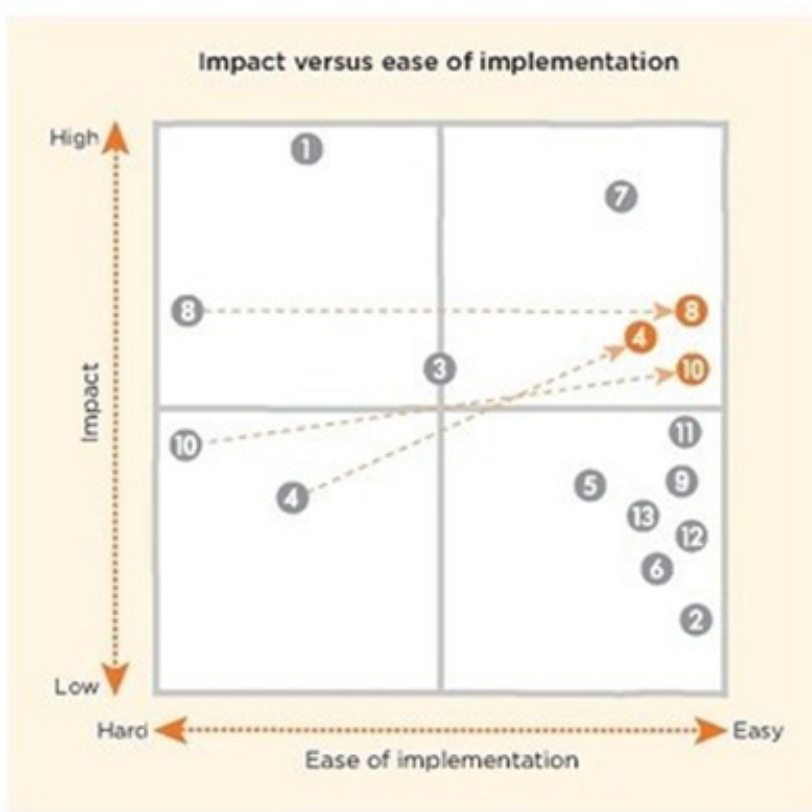

Gambar 2. Matrix Pemilihan Alternatif Solusi (Ken Watanabe, 2009)

\section{Tahap 4. Memilih Alternatif Terbaik}

Dalam menentukan alternatif yang tepat bagi akar permasalahan tim menggunakan matrik pada Gambar 2, untuk memudahkan proses pemilihan alternatif solusi.

\section{HASIL DAN PEMBAHASAN}

Pengabdian ini dilakukan pada periode Januari 2019-April 2020. Program pengabdian mengalami kendala pelaksanaan, dikarenakan adanya Covid -19 , tetapi hal ini dapat diatasi melalui pelatihan dan pendampingan secara online. Khusus untuk kegiatan tertentu tim terpaksa melakukan secara tatap muka, akan tetapi tetap memperhatikan protokol kesehatan. Telah dijelaskan sebelumnya bahwa program pengabdian ini teridiri dari 4 (empat) tahap. Pada bagian ini akan dijelaskan proses yang dilakukan serta luaran yang dihasilkan pada setiap tahap tersebut.

\section{Tahap 1. Memahami Situasi}

Pada tahap ini tim mengumpulkan data menggunakan studi pustaka melalui laporan kegiatan program studepreneur untuk mengetahui berapa jumlah wirausaha baru yang dihasilkan. Laporan hasil monitoring dan evaluasi program studepreneur juga dianalisis, untuk mendapatkan informasi perkembangan bisnis anggota yang sudah lulus dari program. Selain menggunakan teknik studi pustaka, tim juga melakukan wawancara terhadap anggota studepreneur terkait kondisi keuangan mereka selama masa pandemic Covid-19.

Hasil pada tahap ini, tim menemukan bahwa bahwa rata-rata hanya $5 \%$ peserta yang tetap menjalankan bisnis setelah 1 tahun lulus dari program, sayangnya sebagian besar bisnis mereka memiliki perkembangan yang lambat, pekerjaan juga dilakukan secara serabutan. Hasil wawancara juga menunjukan $100 \%$ anggota studepreneur mengalami kesulitan keuangan, sehingga sulit menjalankan bisnis pada masa pandemic Covid-19. Tim juga menemukan dari hasil monitoring dan evaluasi menunjukan rendahnya skor tata kelola. Adanya perkembangan bisnis yang lambat, pekerjaan dilakukan secara serabutan, permasalahan keuangan pada masa Covid-19, serta rendahnya skor tata kelola, menunjukan peserta studeprenenur menghadapi masalah buruknya tata kelola, tetapi pada tahap ini tim belum dapat secara detail menentukan akar permasalahan, maka dilanjutkan ke tahap berikutnya.

\section{Tahap 2. Mengindentifikasi Akar Permasalahan}

Berdasarkan data yang diperoleh pada Tahap 1, tim membuat hipotesis bahwa akar permasalahan adalah tata kelola keuangan dan tata kelola SDM. Rasional dari hipotesis tersebut adalah perkembangan bisnis yang lambat karena kekurangan SDM kompeten, serta kesulitan keuangan pada masa pandemic seharusnya dapat diminimalkan dengan tata kelola keuangan dan SDM yang baik. Hal ini masuk dalam kategori kompetensi kewirausahaan (entrepreneurial competence). Berdasarkan hasil penelitian yang dilakukan oleh (Sari \& Sari, 2018) mengungkap bahwa kinerja organisasi dipengaruhi secara signifikan oleh kompetensi kewirausahaan. Untuk menguji hipotesis ini, maka tim membuat survei. Tabel 1 menjelaskan hasil survei yang dilakukan tim. Berdasarkan hasil tersebut terlihat jelas bahwa anggota studepreneur memang tidak memiliki perencanaan keuangan dan SDM yang baik, sehingga bisa disimpulkan hipotesis terbukti, bahwa akar permasalahan dari buruknya tata studekelola adalah tidak adanya perencanaan keuangan dan SDM. 
Rinaldo, dkk - Perencanaan Keuangan dan Sumber Daya Manusia ...

\begin{tabular}{|c|c|c|c|c|c|c|}
\hline No & Keterangan & Sangat baik & Baik & Cukup & Buruk & Sangat buruk \\
\hline A & PERENCANAAN KEUANGAN & & & & & \\
\hline \multirow{6}{*}{1} & Apakah anda menyisihkan $\mathrm{d}$ & na darurat & & & & \\
\hline & a. Menyisihkan secara rutin dengan jumlah tetap & & & & & \\
\hline & b. Menyisihkan secara rutin dengan jumlah tidak tetap & & & & & \\
\hline & c. menyisihkan tidak rutin & & & 6 & & \\
\hline & d. tidak menyisihkan & & & & 14 & \\
\hline & e. Tidak paham sama sekali & & & & & 5 \\
\hline \multirow[t]{6}{*}{2} & Apakah anda memiliki cicilan dalam $b$ & nis yang anda & alani & & & \\
\hline & a. Tidak ada karena bisnis sudah bisa menghasilkan kas besar & & & & & \\
\hline & b. Ada namun utang produktif kurang dari $30 \%$ dari pendapatan & & & & & \\
\hline & c. Ada lebih dari $30 \%<50 \%$ dari pendapatan & & & & & \\
\hline & d. Ada lebih dari $50 \%$ dari pendapatan & & & & & \\
\hline & e. Tidak paham berapa cicilan yang diperbolehkan, namun membutuhkan dana & & & & & 25 \\
\hline \multirow[t]{6}{*}{3} & Apakah anda menetapkan \% kebutuhan prik & adi dari penda & atan bers & & & \\
\hline & a. Menentapkan (tidak lebih dari $40 \%$ ) & 1 & & & & \\
\hline & b. Menetapkan (20\%-30\%) & & 1 & & & \\
\hline & c. Tidak menetapkan tapi selalu berupaya menjaga tidak melebihi pendapatan & & & 2 & & \\
\hline & d. Tidak menentapkan uang bisnis bercampur dengan uang pribadi & & & & 21 & \\
\hline & e. Tidak mampu mengidentifikasi pendapatan dan kebutuhan & & & & & \\
\hline B & \multicolumn{6}{|l|}{ PERENCANAAN SDM } \\
\hline \multirow[t]{6}{*}{1} & \multicolumn{6}{|c|}{ Apakah anda menghitung jumlah kebutuhan SDM } \\
\hline & a. Melakukan berdasarkan aktivitas,target pendapatan dan std waktu pengerjaan & & & & & \\
\hline & b. Melakukan berdasarkan target pendapatan dan aktivitas & & & & & \\
\hline & c. Disesuaikan dengan aktivitas perusahaan & & & 4 & & \\
\hline & d. Tidak melakukan akan tetapi tau teorinya & & & & 21 & \\
\hline & e. Tidak paham sama sekali dan tidak melakukan & & & & & \\
\hline \multirow[t]{6}{*}{2} & Apakah membuat deskripsi pekerjaan 8 & spesifikasi pek & rjaan & & & \\
\hline & a. Membuat untuk semua pekerjaan secara formal dan tercatat & & & & & \\
\hline & b. Membuat untuk pekerjaan tertentu saja secara formal dan tercatat & & & & & \\
\hline & c. Membuat tidak formal dan tidak tercatat & & & 15 & & \\
\hline & d. Mengetahui deskripsi dan spesifikasi pekerjaan tapi tidak memikirkannya & & & & 10 & \\
\hline & c. Tidak paham & & & & & \\
\hline \multirow[t]{6}{*}{3} & Apakah pekerjaan dilakukan se & ara serabutan & & & & \\
\hline & a. Tidak sama sekali & & & & & \\
\hline & b. Beberapa pekerjaan saja & & & & & \\
\hline & c. Separuhnya & & & 13 & & \\
\hline & d. Sebagian besar & & & & 12 & \\
\hline & e. Semua & & & & & \\
\hline \multirow[t]{6}{*}{4} & Apakah ada program pelatihan ber & ala bagi pegau & & & & \\
\hline & a. Ada dilakukan secara rutin & & & & & \\
\hline & b. Ada namun tidak rutin & & & & & \\
\hline & c. Ada tidak rutin untuk pegawai tertentu saja & & & 2 & & \\
\hline & d. Tidak ada, akan tetapi setuju karyawan butuh pelatihan & & & & 23 & \\
\hline & e. Tidak perlu & & & & & \\
\hline \multirow[t]{6}{*}{5} & Apakah memiliki proses rekrutmen yang $\mathrm{t}$ & rstruktur dan s & stematis & & & \\
\hline & a. Ada terstruktur dan sistematis & & & & & \\
\hline & b. Ada tidak sepenuhnya terstruktur dan sistematis & & & & & \\
\hline & c. Ada tetapi tidak sama sekali terstruktur dan sistematis & & & 10 & & \\
\hline & d. Tidak ada sistem , perekrutan berdasarkan kedekatan & & & & 15 & \\
\hline & c. Tidak mampu mengidentifikasi kebutuhan pegawai & & & & & \\
\hline
\end{tabular}

Gambar 3. Survei Tata Kelola Keuangan dan SDM

Berdasarkan hasil survei diperoleh data bahwa dari 25 anggota studepreneur hanya 6 anggota yang menyisihkan dana darurat tetapi tidak rutin melakukannya, sementara 14 anggota tidak menyisihkan akan tetapi mengetahui perlunya dana darurat dalam bisnis, sedangkan 5 anggota tidak paham perlunya dana darurat dalam bisnis. Hasil identifikasi awal semua anggota studepreneur membutuhkan dana untuk mengembangkan bisnis mereka, akan tetapi berdasarkan hasil survei ternyata 25 anggota studepreneur (100\%) tidak mengetahui berapa besaran cicilan yang diperbolehkan. Anggota studepreneur juga tidak menetapkan persentase pendapatan bersih dari bisnis, yang dapat mereka sisihkan untuk kebutuhan pribadi mereka. Yushita (2017) menyatakan bahwa kesulitan keuangan bukan hanya disebabkan penghasilan yang sedikit tapi juga oleh buruknya pengeloalaan keuangan diantaranya buruknya perencanaan keuangan. 
Dari perspektif manajemen sumber daya manusia 21 peserta tidak menghitung jumlah kebutuhan SDM, sementara 4 peserta lainnya menentukan hanya berdasarkan aktivitas yang ada pada bisnis mereka. Terkait job analysis (job description dan job specification) seluruh peserta memiliki pengetahuan yang baik tentang hal ini, akan tetapi tidak menerapkannya dengan baik. Ada 15 peserta yang membuat job description dan job specification tetapi tidak formal, artinya tidak tertulis dan disosialisasikan kepada karyawan, sementara itu 10 peserta tidak membuat sama sekali. Job analysis ini sangat penting karena mempunyai tujuan untuk memperoleh informasi yang berkaitan dengan berbagai jenis pekerjaan. Beberapa tahapan dalam penyusunan jobanalysis diantaranya: (1) Identifikasi dan pisahkan tugas komponen dalam pekerjaan; (2) Perhatikan bagaimana tugas dilakukan; (3) Identifikasi bidang tanggung jawab utama; (4) Perhatikan kondisi kerja yang berlaku sehubungan dengan aspek fisik, sosial dan keuangan pekerjaan tersebut; dan (5) Identifikasi tuntutan pribadi yang dibuat oleh pekerjaan pada calon individu (Chang \& Kleiner, 2002).

Pada umumnya pekerjaan dalam bisnis anggota studeprenenur dilakukan secara serabutan. Fenomena ini juga ditemukan sebagian besar UMKM yang ada di Indonesia, di mana struktur organisasi belum dibuat sehingga tidak jelas alur komandonya. Sebagaimana yang diungkapkan oleh (Singh, 2009) terdapat beberapa kebutuhan dalam penyusunan struktur organisasi ini, misalnya: teknologi, inovasi, budaya nasional, lingkungan operasi, arahan strategis, siklus hidup organisasi, dan keragaman. Dengan demikian pemimpin organisasi harus cakap dalam mengadopsi proses pembaruan berkelanjutan karena kebutuhan tersebut bersifat dinamis. Dinamika ini menciptakan situasi di mana pemimpin harus menggunakan sumber daya intelektual dan keuangan untuk menjaga organisasi berjalan dengan optimal.

Program pelatihan terstruktur dan secara rutin tidak dimiliki oleh seluruh anggota studepreneur. Proses seleksi yang dilakukan tidak secara terstruktur dan sistematis, proses perekrutan pegawai pada umumnya dilakukan berdasarkan kedekatan saja.

\section{Tahap 3. Mengembangkan Tindakan}

Setalah mengetahui akar permasalahan, maka selanjutnya tim menyusun alternatif solusi bagi permasalahan. Berdasarkan akar permasalahan buruknya perencanaan keuangan dan SDM terdapat 4 alternatif solusi yang dapat ditawarkan. Berikut daftar alternatif solusi:

1. Melakukan pelatihan perencanaan keuangan dan SDM.

2. Mendatangkan ahli profesional untuk menyusun perencanaan keuangan dan SDM untuk melakukan pendampingan.

3. Melakukan pendampingan pada seluruh anggota studepreneur.

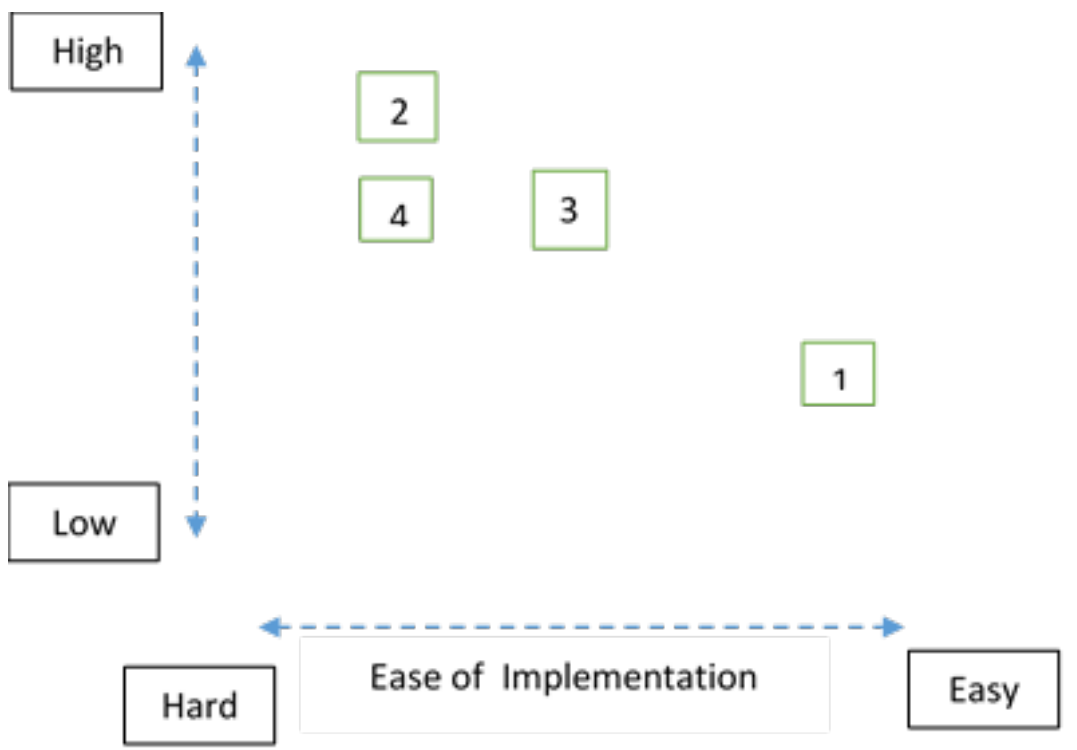

Gambar 4. Proses Penentuan Solusi Menggunakan Matriks 
4. Membiayai peserta mengikuti pelatihan profesional.

\section{Tahap 4. Memilih Alternatif Terbaik}

Pada tahap ini alternatif solusi akan dianalisis untuk menentukan solusi yang akan diimplementasikan. Tim menggunakan alat bantu berupa matrik untuk pengambilan keputusan. Gambar 4 menunjukkan matriks memilih alternatif solusi untuk masalah yang diidentifikasi pada Tahap 3.

Berdasarkan gambar di atas dapat disimpulkan bahwa:

a. Alternatif 1. Pelatihan Perencanaan Keuangan dan SDM

Alternatif ini mudah dilaksanakan karena disaat pandemic seperti ini pelatihan dapat dilakukan secara online. Biaya yang dikeluarkan tidak terlalu mahal jika dibandingkan alternatif lain. Alternatif ini juga sangat mungkin dilakukan karena tim memiliki latar belakang pendidikan pada bidang manajemen keuangan dan manajemen sumber daya manusia.

b. Alternatif 2. Mendatangkan Ahli Profesional untuk Melakukan Pendampingan

Alternatif ini memiliki dampak sangat besar, akan tetapi biaya yang dibutuhkan sangat besar, sehingga sulit untuk dilaksanakan, mengingat anggaran yang dimiliki tim untuk program pengabdian ini sangat terbatas.

c. Alternatif 3. Melakukan Program Pendampingan

Alternatif ini membutuhkan waktu dan biaya yang sedikit lebih besar dari pelatihan, namun masih memungkinkan dilakukan oleh tim. Kendalanya hanya pada keterbatasan tatap muka dengan peserta, namun tetap bisa dilakukan dengan menggunakan protokol kesehatan.

d. Alternatif 4. Membiayai Peserta Mengikuti Pelatihan Profesional

Dampaknya akan sangat besar, akan tetapi biaya yang dibutuhkan juga sangat besar, sehingga untuk saat ini sulit bagi tim mewujudkannya.

Dari 4 alternatif hal yang paling memungkinkan adalah alternatif solusi 1 (satu) dan 3 (tiga). Kedua alternatif ini mungkin dilakukan karena sumber daya yang dimiliki tim cukup untuk menjalankannya.

\section{Hasil Pelatihan Perencanaan Keuangan}

Materi pelatihan perencanaan keuangan diadopsi dari konsep perencanaan keuangan yang disarankan oleh Rudiyanto (direktur PT. Panin Asset Management), yaitu:10+20+30+40. Pendapatan dari penjualan produk dapat dialokasikan berdasarkan rumusan tersebut $10 \%$ untuk kebaikan dan ibadah, 20\% untuk investasi, 30\% untuk membayar cicilan dan 40\% beban operasional bisnis. Untuk memudahkan peserta memahami materi ini tim membuatkan formulir khusus untuk simulasi. Gambar 4 merupakan contoh formulir tersebut. Berikut tahapan pelatihan perencanaan keuangan.

1. Mengidentifikasi Pemasukan dan Pengeluaran Perusahaan

Pada tahap ini tim bersama peserta studepreneur mengidentifikasi pemasukan dan pengeluaran bisnis masing-masing.

2. Membuat Laporan Arus Kas

Setelah mengidentifikasi pemasukan dan pengeluaran, selanjutnya peserta studepreneur akan diberikan pelatihan membuat arus kas, berdasarkan pemasukan dan pengeluaran yang sudah diidentifikasi sebelumnya.

\begin{tabular}{|l|l|l|}
\hline Penerimaan dari piutang & $x x x x$ & \\
\hline Penerimaan dari pinjaman & $x x x x$ & \\
\hline Penerimaan lain-lain & $x x x x$ & \\
\hline TOTAL PENERIMAAN & & \\
\hline PENGELUARAN & & \\
\hline Beban bahan baku & $x x x x$ & \\
\hline Beban tenaga kerja & $x x x x$ & \\
\hline Beban listrik & $x x x x$ & \\
\hline Beban penyusutan & $x x x x$ & \\
\hline Beban sewa & $x x x x$ & \\
\hline Beban pajak & $x x x x$ & \\
\hline Beban... & $x x x x$ & \\
\hline Pembayaran pinjaman & $x x x x$ & \\
\hline TOTAL PENGELUARAN & & $\mathbf{x x x x}$ \\
\hline SELISIH SALDO KAS & & $\mathbf{x x x x}$ \\
\hline SALDO KAS AWAL & $\mathbf{x x x x}$ \\
\hline SALDO TERSEDIA UNTUK PERENCANAAN & & $\mathbf{x x x x}$ \\
\hline Penyusutan & & \\
\hline SALDO KAS AKHIR & & \\
\hline
\end{tabular}

Gambar 5. Laporan Arus Kas 
Rinaldo, dkk - Perencanaan Keuangan dan Sumber Daya Manusia ...

\begin{tabular}{|c|c|c|c|c|c|c|c|c|}
\hline \multirow{3}{*}{ No } & \multirow{3}{*}{ Keterangan } & \multicolumn{7}{|c|}{ Laba Operasi (Laba sebelum bunga dan pajak) (Rp) } \\
\hline & & \multirow{2}{*}{$10 \%$} & \multicolumn{3}{|c|}{$20 \%$} & \multirow{2}{*}{$30 \%$} & \multirow{2}{*}{$40 \%$} & \multirow{13}{*}{ Total } \\
\hline & & & Dana Darurat & Investasi & Asuransi & & & \\
\hline 1 & Kebaikan (Zakat, santunan dII) & & & & & & & \\
\hline 2 & Dana Darurat (Tabungan) & & 0 & & & & & \\
\hline 3 & Investasi pada saham & & & 0 & 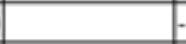 & & & \\
\hline 4 & Investasi Reksadana & & & & 0 & & & \\
\hline 5 & Investasi Emas & & & & & & & \\
\hline 6 & Asuransi & & & & & & & \\
\hline 7 & Cicilan Peralatan & & & & & 0 & & \\
\hline 8 & Cicilan Bangunan & & & & & & & \\
\hline 5 & Kebutuhan pribadi pemilik & & & & & & 0 & \\
\hline & & & & & & & & \\
\hline & Total & & & & & & & \\
\hline
\end{tabular}

Gambar 6. Formulir Perencanaan Keuangan

3. Mendistribusikan Saldo Kas Akhir ke Formulir Perencanaan Keuangan

Output laporan arus kas yang dibuat pada Tahap 2 (dua) adalah saldo kas akhir, yang selanjutnya akan didistribusikan kedalam pos-pos pada formulir perencanaan keuangan.

Berikut salah satu hasil pelatihan perencanaan keuangan dari salah satu peserta studepreneur

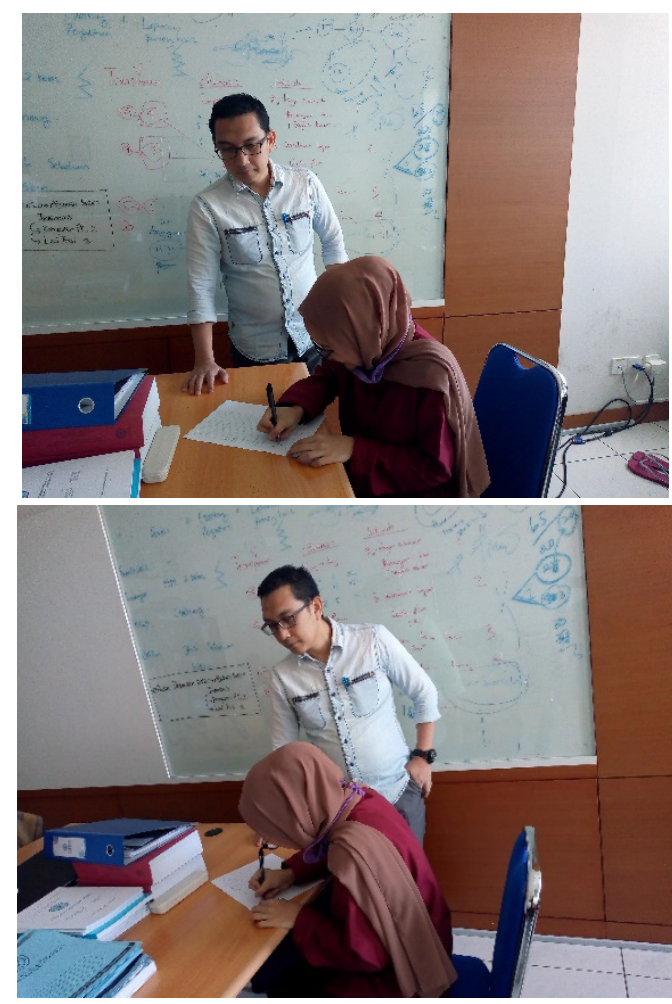

Gambar 7. Pendampingan Studepreneur

\begin{tabular}{lrr}
\hline PENERIMAAN & 26.450 .000 \\
Penerimaan Kas & 1.250 .000 \\
Penerimaan lain-lain & \multicolumn{2}{c}{$\mathbf{2 7 . 7 0 0 . 0 0 0}$} \\
\hline TOTAL PENERIMAAN & \multicolumn{2}{c}{} \\
PENGELUARAN & 10.106 .000 \\
Beban tenaga kerja & 1.200 .000 \\
Beban listrik & 1.500 .000 \\
Beban internet & 3.200 .000 \\
Beban sewa & 2.000 .000 \\
Beban Penyusutan & 5.600 .000 \\
Pembayaran pinjaman & & $\mathbf{2 3 . 6 0 6 . 0 0 0}$ \\
\hline TOTAL PENGELUARAN & $\mathbf{4 . 9 0 4 . 0 0 0}$ \\
SELISIH SALDO KAS & & 3.150 .000 \\
\hline SALDO KAS AWAL & & $\mathbf{7 . 2 4 4 . 0 0 0}$ \\
\hline SALDO KAS TERSEDIA UNTUK & & $\mathbf{2 . 0 0 0 . 0 0 0}$ \\
\hline PERENCANAAN & & $\mathbf{9 . 2 4 4 . 0 0 0}$ \\
\hline PENYUSUTAN & & \\
\hline SALDO KAS AKHIR & & \\
\hline
\end{tabular}

Gambar 8. Contoh Laporan Arus Kas yang Dilakukan oleh Anggota Studepreneur

*Khusus untuk penyusutan disisihkan dan tidak didistribusikan ke dalam form perencanaan, dengan tujuan sebagai cadangan apabila aset yang disusutkan tersebut perlu diganti atau diperbaiki, karena itu pada awal dimasukan ke dalam pengeluaran agar mengurangi kas sehingga kas yang tersedia untuk perencanaan tidak tergabung dengan kas yang harus disisihkan untuk keperluan perbaikan peralatan, renovasi bangunan dan pos lainnya yang berhubungan dengan penyusutan (aktiva tetap). Setelah didapat saldo kas tersedia untuk perencanaan, penyusutan dapat ditambahkan kembali untuk mengetahui saldo kas sesungguhnya yang dimiliki perusahaan. 


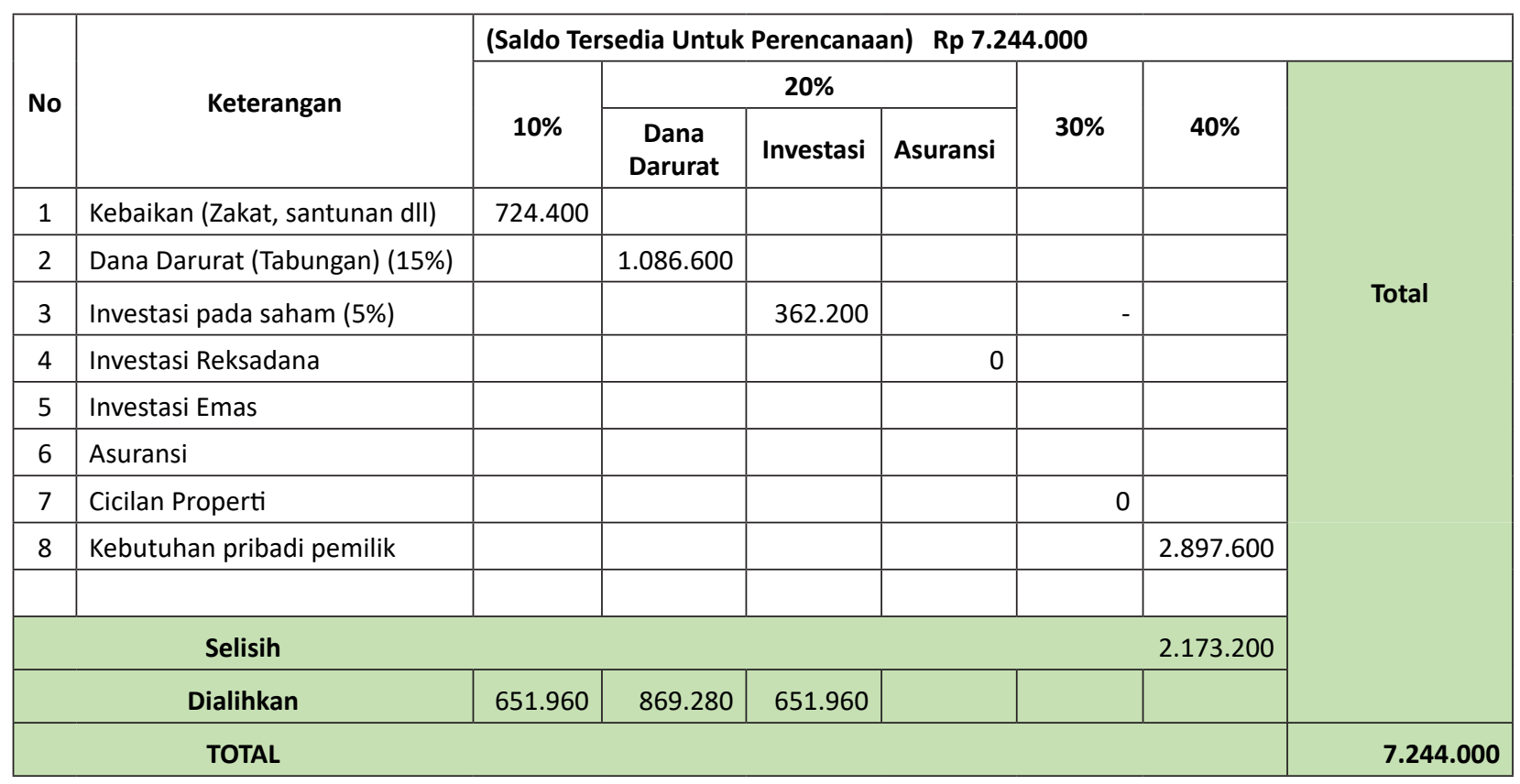

Gambar 9. Contoh Perencanaan Keuangan yang Dilakukan oleh Anggota Studepreneur

Setelah arus kas dibuat, maka selanjutnya adalah mendistribusikan saldo kas akhir ke dalam form perencanaan keuangan.

Pada tabel di atas terdapat pengalihan dana dari cicilan ke post lainnya, hal ini karena peserta tersebut saat ini dan dalam waktu dekat tidak akan menggunakan cicilan, maka dana 30\% untuk cicilan bisa dialokasikan ke post lain. Peserta tersebut memutuskan untuk mengalokasikan untuk kebaikan 30\%, dana darurat $40 \%$ dan investasi saham 30\%.

Hasil pendampingan dan pelatihan perencanaan keuangan dapat membantu pemilik dan manajemen perusahaan mengelola keuangan dengan baik, sehingga perusahaan mampu menghadapi berbagai situasi termasuk masa krisis seperti yang terjadi dimasa pandemic Covid-19. Ketersediaan kas merupakan hal penting bagi perusahaan, dalam prinsip dasar manajemen keuangan kas adalah raja (Keown et al. 2005). Kas sangat dibutuhkan untuk operasional perusahaan. Pada masa krisis sering kali perusahaan mengalami kesulitan kas, hal ini akan dapat dihindari dengan perencanaan keuangan yang baik.

\section{Hasil Pelatihan SDM}

Pendampingan dan pelatihan perencanaan SDM dilakukan setelah peserta mengikuti pendampingan dan pelatihan perencanaan keuangan. Berikut salah satu hasil pelatihan SDM dari salah satu anggota studepreneur. Pada tahap pertama tim dan peserta studepreneur akan menganalisis pekerjaan yang dibutuhkan. Tim mengambil sample usaha barbershop yang dijalankan peserta studepreneur. Berikut pekerjaan-pekerjaan yang berhasil dianalisis dari sebuah barbershop.

\section{Barberman}

2. Senior Barberman

3. Kasir

4. Manajer area barbershop

5. Marketing

6. Administrasi dan keuangan

7. Kebersihan

Setelah diidentifikasi pekerjaan-pekerjaan yang dibutuhkan, maka dibuat job description dan job specification.

\section{Lob Description}

1. Barberman

Karyawan yang bertugas melayani pelanggan yang membutuhkan jasa cukur, cuci, dan creambath rambut, setiap barberman juga bertanggung jawab terhadap kebersihan dan kerapihan alat cukur pada loker masing-masing. 
a. Wewenang

- Mengusulkan kepada senior barberman mengenai standar kulaitas pelayanan

- Meminta bagian kebersihan untuk membersihkan peralatan dan perlengkapan

- Mengusulkan kepada senior barberman mengenai kebutuhan perlatan dan perlengkapan.

b. Kewajiban

- Memberikan pelayan yang baik pada pelanggan

- Menjaga kebersihan tempat kerja termasuk peralatan dan perlengkapan kerja.

- Menggunakan perlengkapan dan peralatan cukur sesuai ketentuan

- Mempelajari model-model rambut terbaru

c. Kode Etik

- Berpakaian rapi

- $\quad$ Berpenampilan menarik

- Tidak mencukur ditempat lain tanpa izin dari perusahaan

- $\quad$ Tidak memberikan fasilitas yang diberikan kepada pihak lain tanpa izin dari perusahaan

d. Hubungan lini

- Manajer area pemasaran

- Senior barberman

e. Kedudukan dalam struktur organisasi

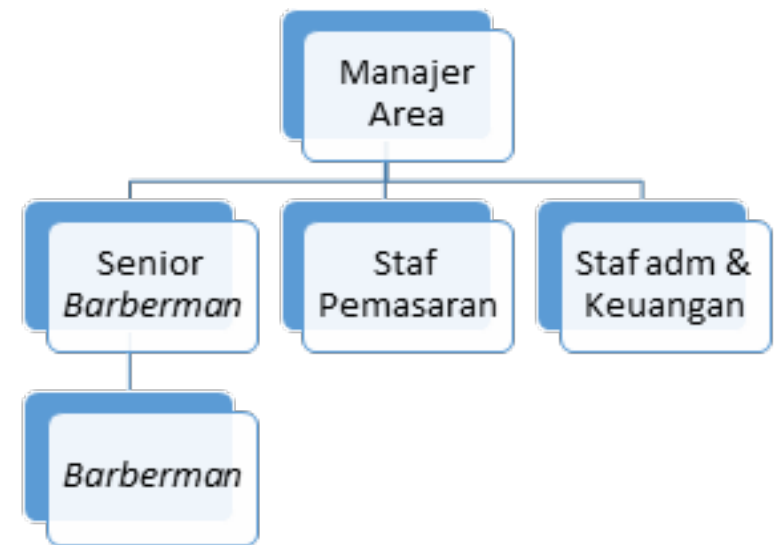

Gambar 10. Contoh Penyusunan Struktur Organisasi yang Sudah Dilakukan oleh Anggota Studepreneur

\section{Lob Specification}

- Usia Min 17 tahun maksimal

- $\quad$ Pendidikan minimal SMA (Sederajat)

- Memiliki kemampuan mencukur rambut berbagai jenis dan model

\section{Menentukan Jumlah Kebutuhan Karyawan}

Dalam menenutkan jumlah kebutuhan karyawan dapat menggunakan metode Workload Analysis. Beberapa penelitian juga menggunakan metode workload dalam menentukan kebutuhan pegawai diantaranya Purnomo (2015) menggunakan metode workload analisis dalam menentukan kebutuhan pegawai bank. (Sari, Hardiansa, \& Suryoputro, 2018) menemukan dengan metode workload bahwa perlunya penambahan 2 pegawai pada Alumunium SME. Metode Workload didasarkan pada beban kerja di waktu tertentu. Cara menghitungnya, yaitu:

WLA $=\frac{\text { Jumlah produk } \times \text { waktu proses tiap unit }}{\text { Hari kerja } \times \text { jam kerja }}$

Target per bulan 900 pelanggan

1 proses cukur rata-rata 30 menit

Total jam kerja 10 jam/ hari x $30=300$ jam perbulan, $300 \mathrm{jam}=18000 \mathrm{menit} / \mathrm{bulan}$

Maka kebutuhan barberman dalam satu barbershop adalah

$$
\begin{aligned}
W L A=\frac{900 \times 30}{18000} & =1,5 \text { barberman } \\
& \approx 2 \text { barberman }
\end{aligned}
$$

Berdasarkan hasil perhitungan di atas barbershop membutuhkan 2 barberman, jika target yang ditetapkan sebanyak 900 pelanggan dalam 1 bulan.

\section{Dampak Pendampingan dan Pelatihan perencanaan keuangan serta SDM}

Hasil pendampingan dan pelatihan perencanaan keuangan serta SDM akan membantu persiapan perusahaan menghadapi situasi krisis. Pelatihan perencanaan keuangan membantu peserta mengalokasikan penghasilan mereka dari bisnis, ke dalam pos investasi, 
Tabel 1. Perbandingan Kondisi Sebelum dan Sesudah Program Pengabdian

\begin{tabular}{|c|c|c|c|c|c|}
\hline \multirow[b]{2}{*}{ No } & \multirow[b]{2}{*}{ Keterangan } & \multicolumn{2}{|c|}{ Kondisi Sebelum } & \multicolumn{2}{|c|}{ Kondisi Sesudah } \\
\hline & & Paham & $\begin{array}{c}\text { Tidak } \\
\text { Paham }\end{array}$ & Paham & $\begin{array}{c}\text { Tidak } \\
\text { Paham }\end{array}$ \\
\hline 1 & $\begin{array}{l}\text { Apakah anda paham berapa dana darurat yang } \\
\text { harus anda sisihkan }\end{array}$ & - & 25 & 25 & - \\
\hline 2 & $\begin{array}{l}\text { Apakah anda mengetahui berapa \% cicilan yang } \\
\text { diperbolehkan dari total pendapatan anda }\end{array}$ & - & 25 & 25 & - \\
\hline 3 & $\begin{array}{l}\text { Apakah anda paham \% pendaptan bisnis yang } \\
\text { bisa disisihkan untuk keperluan pribadi dari }\end{array}$ & 4 & 21 & 25 & - \\
\hline 4 & $\begin{array}{l}\text { Apakah anda paham praktik menganalisis } \\
\text { pekerjaan }\end{array}$ & 10 & 15 & 25 & - \\
\hline 5 & $\begin{array}{l}\text { Apakah anda paham implementasi spesifikasi dan } \\
\text { deskripsi pekerjaan }\end{array}$ & 2 & 23 & 25 & - \\
\hline 6 & $\begin{array}{l}\text { Apakah anda paham cara menghitung kebutuhan } \\
\text { Pegawai }\end{array}$ & - & 25 & 25 & - \\
\hline
\end{tabular}

dana darurat, cicilan, kebutuhan dan pos kebaikan secara tepat. Pendampingan dan Pelatihan perencanaan SDM membantu anggota studepreneur memperoleh dan membentuk SDM perusahaan menjadi keunggulan bersaing dalam bisnis, sehingga bisnis yang lambat berkembang bisa teratasi, mengingat SDM merupakan faktor utama yang menggerakan perusahaan. Tabel 1 menunjukkan perbandingan kondisi sebelum dan sesudah program pengabdian.

Berdasarkan data di atas, maka dapat disimpulkan program pengabdian berjalan efektif, karena mampu $100 \%$ peserta mampu memahami materi dan mengerti bagaimana menerapkan materi dalam praktik bisnisnya. Efektivitas mencapai 100\% ini dapat dicapai karena: (1) Materi yang diberikan sudah didesain untuk mudah dipahami oleh orang berlatar belakang non-ekonomi, (2) Latar belakang dari peserta studepreneur yang merupakan mahasiswa ekonomi, mempermudah meraka dalam memahami materi, akan tetapi dalam menjalani program tim juga mendapatkan beberapa kendala diantaranya sulit melakukan tatap muka, karena kondisi pandemic Covid-19. Kondisi ini memaksa beberapa materi pada akhirnya disampaikan secara daring. Tatap muka tetap perlu dilakukan terutama dalam pengisian formulir perencanaan keuangan. Permasalahan ini akhirnya diatasi dengan tatap muka di kelas yang diatur menjadi 2 shift pertemuan. Hal ini dilakukan agar tidak terlalu banyak siswa yang ada di dalam kelas, sehingga dapat mengatur jarak antarsiswa, selain itu juga siswa diwajibkan menggunakan masker, serta menjalankan protokol kesehatan lainnya.

\section{SIMPULAN}

Permasalahan peserta studepreneur adalah buruknya tata kelola bisnis mereka. Akar permasalahan tata kelola tersebut diantaranya adalah buruknya perencanaan keuangan dan SDM, karena itu program pengabdian yang dilakukan tim adalah pendampingan dan pelatihan perencanaan keuangan dan SDM. Hasil dari program pengabdian menunjukkan ada kemajuan yang signifikan dari anggota studepreneur dalam melakukan perencanaan keuangan dan SDM, para peserta telah dibekali panduan serta pengetahuan menggunakannya, seperti pengetahuan tahapan pengisian form perencanaan keuangan, implementasi analisis pekerjaan, job description, job specification dan menghitung kebutuhan pegawai. Program pengabdian selanjutnya yang dapat dilakukan adalah memperbaiki tata kelola dari perspektif proses bisnis internal dan marketing, berdasarkan hasil pengamatan kedua hal tersebut perlu dilakukan karena banyak peserta yang belum memahami penerapan konsep pemasaran dan proses bisnis internal secara baik. Diharapkan melalui program pengabdian 
ini dapat membantu anggota studepreneur menjadi lebih berkembang dan mandiri serta siap menghadapi situasi krisis.

\section{PERSANTUNAN}

Ucapan terima kasih dan apresiasi diberikan kepada LPPM STIE Ekuitas yang telah memfasilitasi baik secara moral dan dana (Hibah Internal Pengabdian kepada Masyarakat) sehingga kegiatan ini dapat terlaksana. Tidak lupa tim ucapkan kepada para anggota studepreneur yang menjadi mitra pada kegiatan ini. Semoga kegiatan ini dapat bermanfaat dan membantu dalam tata kelola bisnis yang dilakukan oleh studepreneur.

\section{REFERENSI}

Chang, W., \& Kleiner, B. H. (2002). How to Conduct Job Analysis Effectively. Management Research News 25(3), 73-81.

Daniri, A.M. (2005). Good Corporate Governance: Concept and Application in the Indonesian Context. PT Ray Indonesia: Jakarta (Translated from Indonesia).

El-fotouh, H.A. (2009). Importance of Corporate Governance for SMEs, paper presented at the Woman in Management, Business, and Public Service, Egypt.

Ken Watanabe (2009). Problem solving 101: a simple book for smart people. E ISBN: 978-1-10102848-3 Penguin Books Ltd, Registered Offices: 80 Strand, London WC2R 0RL, England

Keown, A., Martin, J., \& Petty, W. (2014). Foundations of Finance - The logic and Practice of Financial Management 8e. In PEARSON. https://doi.org/10.2307/2326337

Purnomo, H. (2015). Workload Analysis for Determining the Number of Employees At Banking Companies. Gema.

Rinaldo, D., Yuneline, M. H., \& Diryana, I. (2017). Implementasi Program Studepreneur Sebagai Upaya Menciptakan Wirausaha Baru dan Model Pengembangan Kewirausahaan Perguruan Tinggi. Jurnal Pengabdian Pada Masyarakat. https://doi.org/10.30653/002.201722.25

Sari, A. D., Hardiansa, F., \& Suryoputro, M. R. (2018). Workload assessment on foundry SME to enhance productivity using full time equivalent. MATEC Web of Conferences, 154, 1-5. https://doi. org/10.1051/matecconf/201815401081

Sari, P. A., \& Sari, W. P. (2018). The Model of Firm Performance Improvement through Entrepreneurial Competence. HOLISTICA 9(3), 55-70.

Singh, S. K. (2009). Structuring Organizations Across Industries in India. Management Research News 32(10), 953-969.

Yushita, A. N. (2017). Pentingnya Literasi Keuangan Bagi Pengelolaan Keuangan Pribadi. Nominal, Barometer Riset Akuntansi Dan Manajemen, 6(1). https://doi.org/10.21831/nominal.v6i1.14330 